\title{
Vitamin C status, serum cholesterol levels and bile composition in the pregnant guinea-pig
}

\author{
BY S. A. JENKINS \\ J. A. Pye Research Centre, Walnut Tree Manor, Haughley Green, Suffolk
}

(Received 14 February 1979 - Accepted 4 August 1979)

\begin{abstract}
I. Pregnant guinea-pigs receiving a low dose of L-ascorbic acid $(0.2 \mathrm{mg} / \mathrm{loog}$ body-weight per d) developed a hypercholesterolaemia in the third trimester of pregnancy, whereas no change in serum cholesterol levels was observed in pregnant animals receiving a higher dose of the vitamin $(2 \mathrm{mg} / 100 \mathrm{~g}$ body-weight per d).

2. Pregnancy in the group of guinea-pigs receiving the higher dose of $L$-ascorbic acid was associated with an increased biliary secretion of bile acids. No change was observed in the biliary secretion of bile acids in pregnant animals receiving the lower dose of $\mathrm{L}$-ascorbic acid, but these animals secreted significantly more cholesterol.

3. Changes in the biliary secretion of cholesterol and bile acids in the pregnant guinea-pig according to $\mathrm{L}$-ascorbic acid intake were reflected in the composition of the gall-bladder bile. Thus, the gall-bladder bile of guinea-pigs receiving the lower dose of L-ascorbic acid contained more cholesterol, while the gall-bladder bile of those animals receiving the higher dose of the vitamin had a higher content of bile acids.

4. The increased cholesterol content of the gall-bladder of pregnant guinea-pigs receiving the lower dose of $\mathrm{L}$-ascorbic acid resulted in decreased bile acid:cholesterol and phospholipid:cholesterol values, conditions predisposing to cholelithiasis.
\end{abstract}

Several studies have indicated a relationship between pregnancy and gallstone formation (Crump, I93 I ; Robertson, I944; Friedman et al. 1966; Comess et al. 1967). Early studies suggested that gall-stone formation in pregnant women was due to qualitative changes in the composition of gall-bladder bile, namely an increased cholesterol concentration and a decreased bile acid concentration (Potter, 1936; Riegal et al. 1936). Similarly, McSherry et al. (1971) reported that the bile of pregnant baboons was supersaturated with respect to cholesterol. On the other hand, Large et al. (I960) observed no differences in the composition of the bile of pregnant women when compared with bile from non-pregnant controls. However, in the latter study, cholic acid was the only bile acid measured.

Recently, a high incidence of cholesterol gall-stones has been reported in hypovitaminotic $\mathrm{C}$ guinea-pigs fed on a high-cholesterol diet (Jenkins, 1977a, $b$ ). Gall-stone formation in these animals was associated with an increased hepatic secretion of cholesterol and a decreased secretion of bile acids, the latter being due primarily to a reduction in the secretion of chenodeoxycholic acid (Jenkins, 1978). Since several studies have shown increased requirements for vitamin C during pregnancy (Martin et al. 1957; Wilson \& Loh, I973; Paul \& Duttagupta, 1974), the following study was undertaken to establish if a reduced ascorbic acid intake during gestation influenced the composition of the bile and hence cholelithiasis.

\section{EXPERIMENTA L}

Animals and diets

For 2 weeks after they were received from the supplier, twenty-four virgin female guineapigs (Dunkin Hartley) weighing 700-800 g were housed singly and allowed access to a standard laboratory diet (Cooper Nutrition, Ltd) and water ad lib. At the end of this period, twelve of the guinea-pigs were mated with 'proven' males of the same strain, the remaining animals serving as non-pregnant controls. After a positive identification of sperm in vaginal 
smears (designated day I of the pregnancy), the female guinea-pigs were isolated and transferred to the scorbutic diet of Ginter et al. (I969). A non-pregnant control guinea-pig was transferred to the vitamin C-deficient diet at the same time as a pregnant animal.

Six pregnant guinea-pigs and six non-pregnant control animals received $0.2 \mathrm{mg}$ L-ascorbic acid (Sigma Ltd, Kingston upon Thames, Surrey)/100 $\mathrm{g}$ body-weight perorally in $0.2 \mathrm{ml}$ sucrose $(200 \mathrm{~g} / \mathrm{l})$ for the duration of the experiment. The remaining animals received $2 \mathrm{mg}$ $\mathrm{L}$-ascorbic acid/100 $\mathrm{g}$ body-weight daily in the same volume of sucrose.

\section{Experimental procedure}

Blood samples were removed from the guinea-pigs by heart puncture under light diethyl ether anaesthesia 12 and $36 \mathrm{~d}$ after being placed on the scorbutic diet. At day 60 after being placed on the scorbutic diet the animals were weighed, anaesthetized by an intraperitoneal injection of Sagatal (May and Baker, Ltd, Dagenham, Essex), and a blood sample obtained by heart puncture. The gall-bladder and biliary tree were exposed and inspected for concretements. After ligation of the cystic duct the gall bladder and its contents were removed and a polyethylene cannula ( $3 \mathrm{FG}$; Portex Ltd, Hythe, Kent) inserted into the common bile duct. Biliary drainage was continued for $15 \mathrm{~min}$, after which time interval the foetuses were removed, weighed and examined for external abnormalities.

\section{Analytical methods}

Serum cholesterol levels were analysed according to the method of Röschlau et al. (1976), and bile cholesterol and phospholipid concentrations were determined as previously described (Jenkins, 1978). Total bile acids in gall bladder and hepatic bile were measured by the method of Talalay (I960) as modified by Admirand \& Small (I968).

\section{Statistical methods}

The statistical significance of any difference between control and experimental groups was evaluated using a Student's $t$ test: $P>0.05$ being regarded as statistically insignificant.

\section{RESULTS}

No signs of distress were observed in any of the pregnant guinea-pigs during gestation, and no external abnormalities were observed in any of the foetuses. Moreover, the body-weight (IOI3 SEM $62 \mathrm{~g}$ ), mean foetal weight ( 99 SEM $2 \mathrm{~g}$ ) or number of foetuses (twenty-two) in the group of pregnant guinea-pigs receiving the lower dose of ascorbic acid did not differ significantly from the body-weight (IO5I SEM $67 \mathrm{~g}$ ), mean foetal weight (I02 SEM $2 \mathrm{~g}$ ) or number of foetuses (twenty-three) in the group of animals receiving the higher dose of the vitamin. Similarly, no significant difference was observed between the body-weights of the virgins receiving the low dose of ascorbic acid daily (860 SEM $2 \mathrm{I} \mathrm{g}$ ) and those receiving the higher dose ( 906 SEM $40 \mathrm{~g}$ ) $60 \mathrm{~d}$ after being placed on the scorbutic diet.

Serum cholesterol levels did not change significantly during the experimental period in either group of virgin guinea-pigs or in the group of pregnant animals receiving the higher dose of ascorbic acid (Table I). However, in the pregnant guinea-pigs receiving the lower dose of ascorbic acid, the serum cholesterol concentration was significantly elevated on day 60 of gestation $(P<0.01)$.

No significant difference was observed between the cholesterol, phospholipid, or bile acid concentrations in the gall-bladder bile of the two groups of virgin guinea-pigs (Table 2). Pregnancy in the group of guinea-pigs receiving the higher dose of ascorbic acid was associated with a significant increase $(P<0.05)$ in the gall-bladder bile acid concentration on the sixtieth day of gestation, and consequently an increased value for bile acid:cholesterol. 
Table I. Serum cholesterol levels of the guinea-pigs during the 60 d experimental period (Mean values with their standard errors for six animals/treatment)

\begin{tabular}{|c|c|c|c|c|c|c|c|}
\hline \multirow[b]{3}{*}{ Group } & \multirow{3}{*}{$\begin{array}{c}\text { Daily dosage } \\
\text { of ascorbic } \\
\text { acid } \\
\text { (mg/ } 100 \mathrm{~g} \\
\text { body-wt) }\end{array}$} & \multicolumn{6}{|c|}{ Concentration (mmol/l) } \\
\hline & & \multicolumn{2}{|c|}{ Day 12} & \multicolumn{2}{|c|}{ Day 36} & \multicolumn{2}{|c|}{ Day 60} \\
\hline & & Mean & SE & Mean & SE & Mean & SE \\
\hline Virgin & 0.2 & $1 \cdot 34$ & 0.06 & $1 \cdot 45$ & $0.1 \mathrm{I}$ & I. 43 & $0.1 \mathrm{I}$ \\
\hline Pregnant & 0.2 & $1 \cdot 38$ & 0.15 & $1 \cdot 44$ & 0.09 & 1.89 & $0.09 *$ \\
\hline Virgin & $2 \cdot 0$ & $1 \cdot 32$ & 0.09 & $1 \cdot 37$ & 0.11 & {$[\cdot 38$} & 0.11 \\
\hline Pregnant & $2 \cdot 0$ & $1 \cdot 46$ & 0.09 & $1 \cdot 40$ & $0.1 I$ & $1 \cdot 46$ & 0.08 \\
\hline
\end{tabular}

* Differences between the dosages of ascorbic acid were significantly different: $P<0.0 \mathrm{I}$.

Table 2. Gall-bladder bile composition of the guinea-pigs $60 d$ after being placed on the scorbutic diet

(Mean values with their standard errors for six animals/treatment)

\begin{tabular}{|c|c|c|c|c|c|c|c|c|c|}
\hline \multirow[b]{3}{*}{ Group } & \multirow{3}{*}{$\begin{array}{c}\text { Daily dosage } \\
\text { of ascorbic } \\
\text { acid } \\
\text { (mg/100 g } \\
\text { body-wt) }\end{array}$} & \multicolumn{6}{|c|}{ Concentration $(\mathrm{mmol} / \mathrm{l})$} & \multirow[b]{3}{*}{ BA:C } & \multirow[b]{3}{*}{ P:C } \\
\hline & & \multicolumn{2}{|c|}{$\begin{array}{l}\text { Bile acids } \\
\text { (BA) }\end{array}$} & \multicolumn{2}{|c|}{$\begin{array}{l}\text { Cholesterol } \\
\text { (C) }\end{array}$} & \multicolumn{2}{|c|}{$\begin{array}{l}\text { Phospholipids } \\
\text { (P) }\end{array}$} & & \\
\hline & & Mean & SE & Mean & SE & Mean & SE & & \\
\hline Virgin & 0.2 & $9 \cdot 44$ & $1 \cdot 58$ & 0.15 & 0.05 & I 24 & 0.89 & 63 & 8 \\
\hline Pregnant & 0.2 & $9 \cdot 11$ & 1.03 & 0.33 & $0.06^{*}$ & $1 \cdot 30$ & 0.11 & 28 & 4 \\
\hline Virgin & 2.0 & 8.69 & 1.65 & 0.12 & 0.05 & $1 \cdot 33$ & 0.10 & 72 & II \\
\hline Pregnant & 2.0 & $14 \cdot 77$ & I. $39^{*}$ & 0.13 & 0.04 & $1 \cdot 21$ & 0.09 & 114 & 9 \\
\hline
\end{tabular}

- Differences between the dosages of ascorbic acid were statistically significant: $P<0.05$.

Table 3. Hepatic bile composition of the guinea-pigs $60 d$ after being placed on the scorbutic diet

(Mean values with their standard errors for six animals/treatment)

\begin{tabular}{|c|c|c|c|c|c|c|c|}
\hline \multirow[b]{3}{*}{ Group } & \multirow{3}{*}{$\begin{array}{l}\text { Daily dosage } \\
\text { of ascorbic } \\
\text { acid } \\
\text { (mg/roo g } \\
\text { body-wt) }\end{array}$} & \multicolumn{6}{|c|}{ Concentration $(\mu \mathrm{mol} / \mathrm{l})$} \\
\hline & & \multicolumn{2}{|c|}{ Bile acids } & \multicolumn{2}{|c|}{ Cholesterol } & \multicolumn{2}{|c|}{ Phospholipids } \\
\hline & & Mean & SE & Mean & $\mathbf{S E}$ & Mean & $\mathbf{S E}$ \\
\hline Virgin & 0.2 & $198 I$ & I10 & 28 & 6 & 230 & 15 \\
\hline Pregnant & 0.2 & 1680 & III & 47 & $5^{*}$ & 229 & 20 \\
\hline Virgin & 2.0 & I $75 \mathrm{I}$ & 180 & 27 & 6 & 211 & 20 \\
\hline Pregnant & $2 \cdot 0$ & $26 I I$ & $160^{*}$ & 24 & 4 & 230 & 17 \\
\hline
\end{tabular}

- Differences between the dosages of ascorbic acid were significantly different: $P<0.05$.

In contrast, while there was no significant increase in the bile acid concentration of the gallbladder bile of the pregnant guinea-pigs receiving the lower dose of ascorbic acid on day 60 of the pregnancy, the cholesterol concentration was significantly elevated $(P<0.05)$. Thus, in these animals, pregnancy was associated with diminished bile acid:cholesterol and phospholipid:cholesterol values. Although qualitative changes were observed in the composition of the gall-bladder bile of the pregnant guinea-pigs, no gall-stones were present in the gall-bladder of any of the experimental animals.

Changes in the composition of the hepatic bile of the experimental animals were similar 
Table 4. Hepatic bile production of the guinea-pig $60 \mathrm{~d}$ after being placed on the scorbutic diet

(Mean values with their standard errors for six animals/treatment)

$\begin{array}{lccc}\text { Group } & \begin{array}{c}\text { Daily dosage of } \\ \text { ascorbic acid } \\ \text { (mg//00 g body-wt) }\end{array} & \overbrace{\text { Mean }}^{\begin{array}{c}\text { Hepatic bile production } \\ \text { (ml/kg body-wt per 24 } \mathrm{h} \text { ) }\end{array}} \text { SE } \\ \text { Virgin } & 0 \cdot 2 & 199 & 13 \\ \text { Pregnant } & 0 \cdot 2 & 163 & 9 \\ \text { Virgin } & 2 \cdot 0 & 206 & \text { II } \\ \text { Pregnant } & 2 \cdot 0 & 160 & \text { II }\end{array}$

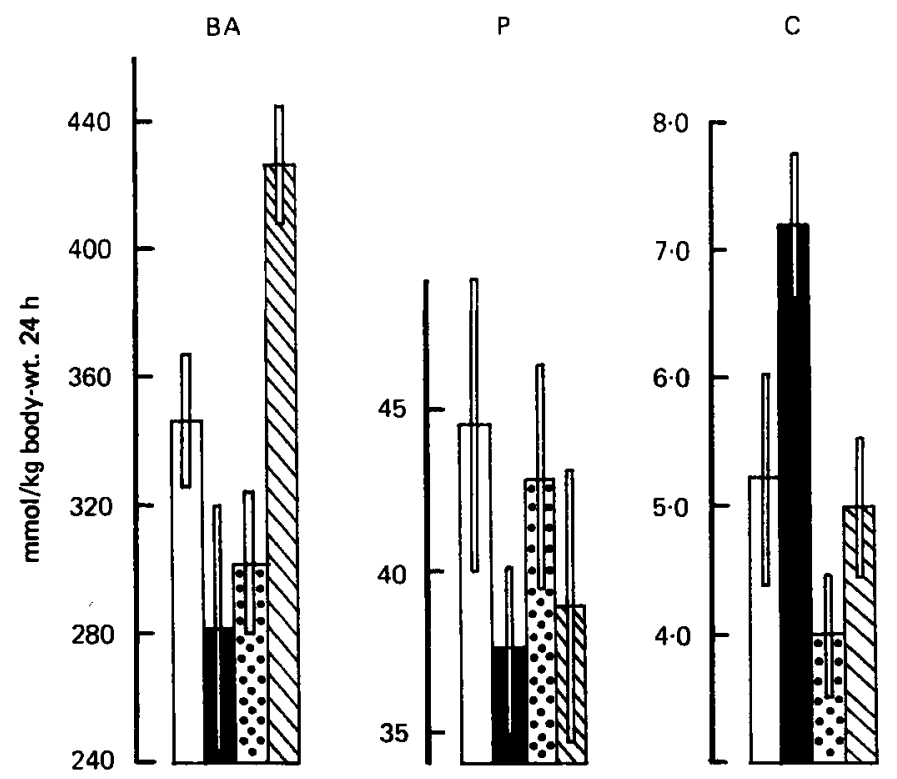

Fig. I. Biliary secretion (mmol/kg body-weight per $24 \mathrm{~h}$ of bile acids (BA): phospholipids (P) and cholesterol $(C)$ by virgin guinea-pigs given orally $0.2(\square)$ or $2($ (ख) $) \mathrm{mg}$ L-ascorbic acid/100 $\mathrm{g}$ body-weight per $d$ and pregnant guinea-pigs given orally $0.2(\mathbb{E})$ or $2(\mathbb{\$}) \mathrm{mg}$ ascorbic acid/100 $\mathrm{g}$ body-weight per $d$, (耳) standard errors of the means.

to those observed in the gall-bladder bile (Table 3). Thus pregnancy in the group of guineapigs receiving the higher dose of ascorbic acid was associated with a significantly higher bile acid concentration $(P<0.05)$, while the hepatic bile of those pregnant animals receiving the lower dose of ascorbic acid contained significantly more cholesterol $(P<0.05)$.

The volume of bile produced by the guinea-pigs was not affected by vitamin $C$ intake (Table 4 ), but it would appear that both groups of pregnant animals secrete significantly less $(P<0.05)$ bile than the two groups of virgins. However, it seems likely that the latter observation is due to the increased weight of the pregnant animals rather than cholestasis, since hepatic bile production is expressed in terms of body-weight. In spite of the decreased volume of bile produced by the pregnant guinea-pigs, those receiving the higher dose of ascorbic acid secreted significantly more $(P<0.05)$ bile acids than the other three groups, while those receiving the lower dose secreted significantly more $(P<0.05)$ cholesterol than the other groups (Fig. I). 


\section{DISCUSSION}

The results indicate that both the dietary levels of ascorbic acid employed in the present study were adequate for maintaining a normal pregnancy in the guinea-pig.

Alterations of serum cholesterol levels during pregnancy vary in different animal species. In rabbits (Zilversmit et al. 1972), baboons (McSherry et al. 1977) and rhesus monkeys (Wolffe et al. 1967) serum cholesterol levels decrease during pregnancy. Conversely, in humans (Svanborg \& Vikrot, 1965; Green, 1966) and in rats (Fillios et al. 1958) serum cholesterol levels increase through gestation. In the present study the serum cholesterol levels of those guinea-pigs receiving the higher dose of L-ascorbic acid did not change significantly during gestation, results in accordance with the previously reported findings of Boyd \& Fellows (1936). However, in those pregnant guinea-pigs receiving the lower dose of L-ascorbic acid a significant hypercholesterolaemia was observed on day 60 of the pregnancy. Hypovitaminosis $\mathrm{C}$ in the guinea-pig is characterized by an increase in the serum cholesterol levels (Ginter et al. 1965; Ginter, 1973). Thus it is possible that the hypercholesterolaemia in the pregnant guinea-pigs receiving the lower dose of ascorbic acid may have been due to a state of latent vitamin C-deficiency resulting from an increased requirement for the vitamin during pregnancy (Martin et al. 1957; Wilson \& Loh, 1973; Paul \& Duttagupta, 1974). The low dose of ascorbic acid would appear to be adequate to prevent a state of hypovitaminosis $\mathrm{C}$ in the virgin guinea-pigs since these animals did not exhibit a hypercholesterolaemia.

Fillios et al. ( $\left.195^{8}\right)$ suggested that the hypercholesterolaemia in pregnant rats was due to an increased synthesis of cholesterol. Similarly, Li et al. (1978), from studies on the faecal excretion of bile acids in the pregnant guinea-pig, suggested that the hypercholesterolaemia of early pregnancy was related to an increase in cholesterol synthesis, while the fall in plasma cholesterol levels in the third trimester was related to an increase in bile acid synthesis and excretion. This suggestion receives support from the present study, which in addition produces further evidence for an involvement of $\mathrm{L}$-ascorbic acid in the conversion of cholesterol to bile acids. Thus when dietary L-ascorbic acid is adequate, the pregnant guinea-pig compensates for an increase in cholesterol biosynthesis by an increased synthesis and secretion of bile acids, thereby preserving a normocholesterolaemia. Conversely, in the pregnant guinea-pig receiving an inadequate dose of L-ascorbic acid there is an impairment in the conversion of cholesterol to bile acids resulting in hypercholesterolaemia and an increased hepatic secretion of cholesterol.

Cholesterol is held in micellar solution in bile in combination with bile acids and phospholipids, and it has been suggested that it is the values for bile acid:cholesterol and phospholipid:cholesterol rather than the absolute value which determines its solubility (Isaksson, 1954). Thus the bile of animals in which cholelithiasis has been induced has reduced values for both bile acid:cholesterol and phospholipid:cholesterol (Caldwell et al. 1965; Osuga \& Portman, 1971; Jenkins, 1977a, b). In the present study, pregnancy in the group of guinea-pigs receiving the higher dose of ascorbic acid was associated with a significant increase in the bile acid concentration of the gall-bladder bile, results in accordance with the observations of Holzbach et al. (197I). Therefore, in these animals the bile acid:cholesterol value was increased, conditions favouring the solubilization of cholesterol. Conversely, in the pregnant guinea-pigs receiving the lower dose of ascorbic acid, an increase in the gall-bladder bile cholesterol concentration resulted in decreased bile acid:cholesterol and phospholipid: cholesterol values, conditions predisposing to cholelithiasis. Although no gall-stones were present in any of the guinea-pigs, the results suggest that, in this species at least, vitamin $\mathrm{C}$ status has an important role in determining the composition of gall-bladder bile and hence cholelithiasis during pregnancy. 
The author would like to thank Dr K. M. L. Morris for valuable advice and discussion; Miss S. Birch, Miss J. Darlington, Mr P. Visser and the late Mr J. A. Rawlings for technical assistance.

\section{REFERENCES}

Admirand, W. H. \& Small, D. M. (1968). J. clin. Invest. 47, 1043.

Boyd, E. M. \& Fellows, M. D. (1936). Am. J. Physiol. 114, 635.

Caldwell, F. J. Jr., Levitsky, K. \& Rosenberg, B. (1965). Am. J. Physiol. 209, 473.

Comess, L. J., Bennet, P. H. \& Burch, T. (1967). New Engl. J. Med. $277,894$.

Crump, C. (1931). Surgery Gynec. Obstet. 53, 447.

Fillios, L. C., Kaplan, R., Martin, R. S. \& Stare, F. J. (1958). Am. J. Physiol. 193, 47.

Friedman, G. D., Kannel, W. B. \& Dauber, T. R. (1966). J. chron. Dis. 19, 273.

Ginter, E. (1973). Science, N.Y. 179, 702.

Ginter, E., Bilisics, I. \& Cerven, J. (1965). Physiologia bohemoslov I4, 466.

Ginter, E., Ondreicka, R., Bobek, P. \& Simko, V. (1969). J. Nutr. 99, 261.

Green, J. C. (1966). Am. J. Obst. Gynec. 95, 387.

Holzbach, R. T., Marsh, M. E. \& Hallberg, M. C. (197I). Gastroenterology 60, 288.

Isaksson, B. (1954). Acta Soc. Med. upsal. 59, 296.

Jenkins, S. A. (1977a). Experientia 33, 1616.

Jenkins, S. A. (1977b). Biochem. Biophys. Res. Commun. 77, 1930.

Jenkins, S. A. (1978). Br. J. Nutr. 40, 317.

Large, A. M., Johnston, C. G., Katsuki, T. \& Fachnie, H. L. (1960). Am. J. med. Sci. 293, 713.

Li, J. R., Bale, L. K. \& Subbiah, M. T. R. (1978). Steroids 3I, 2288.

MeSherry, C. K., Deitrick, J. E., Mary, P. S., Niemann, W., Morissey, K. P., Palmer, R. H. \& Glenn, F. (1977). Surgery Gynec. Obstet, 144, 727.

McSherry, C. K., Javitt, N. B., Carvalho, J. M. \& Glenn, F. (1971), Ann. Surg. 173, 569.

Martin, M. P., Bridgforth, E., McGinty, W. J. \& Darby, W. J. (1957). J. Nutr. 62, 201.

Osuga, T. \& Portman, O. (1971). Proc. Soc. exp. Biol. Med. 136, 722.

Paul, P. K. \& Duttagupta, P. N. (1974). Fert. Steril. 25, 68.

Potter, M. G. (1936). J. Am. med. Ass. 106, 1070.

Riegal, C., Ravdin, I. S. \& Johnston, C. G. (1936). Surgery Gynec. Obstet. 62, 933.

Robertson, H. E. (1944). Int. Abstr. Surg. Gynec. Obstet. 78, 193.

Röschlau, P., Bernt, E. \& Gruber, W. (1976). Z. Klin. Chem. U. Klin. Biochem. 12, 403.

Svanborg, A. \& Vikrot, O. (1965). Acta med. Scand. 178, 615.

Talalay, P. (1960). Meth. biochem. Analysis 8, 119.

Wilson, C. W. M. \& Loh, H. S. (1973). Lancet ii, 859.

Wolfe, R. C., Tempte, L. \& Meyer, R. K. (1967). Proc. Soc. exp. Biol. Med. 125, 1230.

Zilversmit, D. B., Hughes, L. B. \& Remmington, M. J. (1972). J. Lipid Res. 13, 750. 